Review

\title{
Research Progress in Corrosion Mechanism of Reinforced Alkali-Activated Concrete Structures
}

\author{
Feng Zhang, Xun Xi (D) and Shangtong Yang *(D) \\ Department of Civil and Environmental Engineering, University of Strathclyde, Glasgow G1 1XJ, UK; \\ feng.zhang@strath.ac.uk (F.Z.); xun.xi@strath.ac.uk (X.X.) \\ * Correspondence: shangtong.yang@strath.ac.uk; Tel.: +44-141-548-3273
}

check for

updates

Citation: Zhang, F.; Xi, X.; Yang, S. Research Progress in Corrosion

Mechanism of Reinforced Alkali-Activated Concrete Structures. Corros. Mater. Degrad. 2021, 2 , 641-656. https://doi.org/10.3390/ cmd2040034

Received: 5 September 2021

Accepted: 1 November 2021

Published: 3 November 2021

Publisher's Note: MDPI stays neutral with regard to jurisdictional claims in published maps and institutional affiliations.

Copyright: (c) 2021 by the authors. Licensee MDPI, Basel, Switzerland. This article is an open access article distributed under the terms and conditions of the Creative Commons Attribution (CC BY) license (https:// creativecommons.org/licenses/by/ $4.0 /)$.

\begin{abstract}
In this paper, the recent research progress on the corrosion of reinforced alkali-activated materials (AAMs) concrete structures is reviewed. The corrosion mechanisms induced by carbonation and chloride ingress in AAMs concrete are discussed, from the perspectives of composition, microstructure and pore solution chemistry, in comparison to ordinary Portland cement (OPC) concrete. The steel-alkali-activated concrete interface is a key to investigating corrosion initiation and propagation, which has different physical and chemical characteristics of the steel-concrete interface in OPC concrete. Moreover, the electrochemical process testing methods including half-cell potential and linear polarization resistance are critically discussed with a focus on what could be inherited from the OPC concrete and what criteria are no longer suitable for AAMs concrete due to underestimation in most cases. New data and theories are urgently needed for using AAMs in concrete structures to replace OPC. At the end of this paper, the research gaps and future research needs are summarised for the sake of widespread application of AAMs in concrete structures for sustainable and low-carbon construction.
\end{abstract}

Keywords: corrosion; alkali-activated materials; reinforced concrete structures; chloride ingress; carbonation; cracking

\section{Introduction}

Ordinary Portland cement (OPC) is the most consumed construction material worldwide due to its excellent performance, such as high mechanical strength especially in compression, high durability, good fire resistance, etc. However, OPC is a high carbon embodied material, emitting $7 \%$ of the global $\mathrm{CO}_{2}$ during its manufacturing process [1]. Furthermore, corrosion of the reinforcement in OPC concrete structures is a severe problem that reduces the service life of the structures. The annual cost for maintenance and replacement of deteriorated concrete structures in the U.S. is reported to be at least USD 8.3 billion [2].

In the last few decades, alkali-activated materials (AAMs) have attracted emerging interest from both the research and commercial perspectives, in light of sustainable development of construction materials [3-5]. It has been acknowledged that AAMs have significant potential to reduce $\mathrm{CO}_{2}$ emission in the construction sector [6] while exhibiting exceptional properties [7]. These materials, such as fly ash, slag and metakaolin, are normally produced from industrial wastes or by-products which also contribute to circular economy. These raw materials need to be chemically activated to yield strength with high-alkaline solutions, leading to better mechanical properties than OPC concretes [8-11]. Two categories of AAMs are usually used by researchers to distinguish the binder type and their related microstructures [3], namely, (1) high-calcium (slag) AAMs for which the microstructure is calcium aluminium silicate hydrate (C-A-S-H); (2) low-calcium (fly ash, metakaolin) AAMs for which the microstructure is sodium aluminosilicate hydrate (N-A-S-H).

Carbonation and chloride ingress are the main corrosion types for reinforced concrete structures. For the carbonation-induced corrosion, AAMs were reported more susceptible to $\mathrm{CO}_{2}$ attack than OPC concrete in an accelerated carbonation test within a high $\mathrm{CO}_{2}$ 
concentration environment [12-15]. The main reason is that AAMs' pore solution does not contain or contains little calcium hydroxide $\left(\mathrm{Ca}(\mathrm{OH})_{2}\right)$, which provides a buffer effect to delay the advancement of $\mathrm{CO}_{2}$ [12]. However, Bernal et al. [16] found the carbonation depth of AAS (alkali-activated slag) concrete, naturally exposed for seven years, is much lower than the value predicted from the accelerated carbonation test. Therefore, using the accelerated carbonation test may not be sufficiently accurate to describe the real carbonation behaviour of AAMs [13,17-20].

Chloride ingress-induced reinforced concrete corrosion, e.g., using deicing salt on reinforced concrete bridges, especially in a marine environment, is much more severe than the carbonation-induced corrosion because of low $\mathrm{CO}_{2}$ concentration in the natural environment [21,22]. Unlike low-carbonation resistance from the accelerated carbonation test, AAMs were reported to have better or comparable chloride ingress resistance [23-25]. Choi et al. [26] found that increasing the content of fly ash in OPC concrete would decrease the chloride penetration rate. Miranda et al. [27] found the passivity rate and degree of reinforcement in chloride-free AAFA (alkali-activated fly ash) mortars were similar to OPC mortars, which have comparable chloride resistance. Khan et al. [28] found that the hydrotalcite phase plays an important role in the chloride binding capability of AAS concrete.

The electrochemical experiments involving open-circuit potential (OCP), half-cell potential, linear polarization resistance and Tafel extrapolation are generally used to monitor the health condition of concrete structures [29]. In many cases, the half-cell potential values for AAMs were reported to be much lower than the OPC concrete [30-33], which means the determination criterion [34] may no longer be suitable for AAMs. Babaee and Castel [35] systemically studied chloride diffusion and threshold of AAMs (blended fly ash and slag) through their electrochemical experiments. They suggested re-defining the Tafel constant (B) value for 45 58 and 13 20 $\mathrm{mV}$ for active and passive specimens, respectively, to replace what has been used so far for OPC concrete, i.e., 26 and $52 \mathrm{mV}$, respectively [36]. Using the criterion designed for OPC may lead to considerable underestimation for corrosion in AAMs.

The passive layer at the steel surface has the ability to protect the steel reinforcement from corrosion but requires a stable and high-alkaline environment [37]. The corrosion mechanism at the steel-concrete interface is complex compared with OPC concrete; for instance, the sulphide products [31] and drying shrinkage [38,39], characteristics of the steel-concrete interface [32], have different effects on it. However, the study on the steelconcrete interface is very limited; the corrosion mechanism, including corrosion initiation, rust accumulation and expansion, in AAMs, remains unclear.

This paper aims to present a comprehensive and critical review of recent progress in understanding the corrosion mechanism of reinforced concrete structures, fully incorporated with alkali-activated materials. The durability of AAMs on the material level has been researched in a significant number of studies $[3,8,9,40]$, but the corrosion behaviour on the structural level when working with steel reinforcement warrants urgent research. We will review carbonation and chloride ingress-caused corrosion in AAM concrete structures, focusing on the characteristics of steel-concrete interface and the electrochemical reaction process and measurement. In the end, we will propose the research gaps, to our best knowledge, for future research to fully depict the structural durability of AAM concretes.

\section{Carbonation and Chloride Ingress}

\subsection{Composition and Microstructure}

The composition of raw materials determines the characteristics of AAMs. A comparison among key compositions of fly ash, slag and OPC from different locations is presented in Table 1. It can be observed that fly ash has two classes, namely, Class F and Class C [41]. There is a slight difference in the composition of raw material of slag [23,35]. To distinguish the class of fly ash, Class C fly ash has over $20 \% \mathrm{CaO}$ (calcium oxide) content in the composition of raw material; otherwise, it is Class F fly ash according to ASTM 
C618 [42]. Currently, most literature focuses on low-calcium fly ash (i.e., class F) in the research of AAM corrosion mechanisms. To compare these three raw materials (fly ash, slag and OPC), fly ash has the highest content of silicon oxide $\left(\mathrm{SiO}_{2}\right)$, which is almost two and three times that of slag and OPC, respectively. Furthermore, the content of aluminium oxide $\left(\mathrm{Al}_{2} \mathrm{O}_{3}\right)$ in fly ash is also higher than the other two materials. In contrast to these two compositions, both slag and OPC are richer in $\mathrm{CaO}$, magnesium oxide $(\mathrm{MgO})$ and sulphur oxide $\left(\mathrm{SO}_{3}\right)$ than class $\mathrm{F}$ fly ash, although the content of the last two compositions is greatly lower than $\mathrm{CaO}$.

Table 1. The key contents (wt. $\%$ ) of FA, SA and OPC, reprinted from refs. [23,35,41].

\begin{tabular}{cccccc}
\hline & Class F Fly Ash (wt.\%) & Class C Fly Ash (wt.\%) & \multicolumn{2}{c}{ Slag (wt.\%) } \\
\hline Source & Babaee and Castel [35] & Shi et al. [41] & Babaee and Castel [35] & Bouteiller et al. [23] & Bouteiller et al. [23] \\
\hline $\mathrm{SiO}_{2}$ & 66.56 & 42.46 & 31.52 & 27.6 \\
$\mathrm{Al}_{2} \mathrm{O}_{3}$ & 22.47 & 19.46 & 12.22 & 8.6 & 5.6 \\
$\mathrm{CaO}$ & 1.64 & 21.54 & 44.53 & 4.62 & 5.7 \\
$\mathrm{MgO}$ & 0.65 & 4.67 & 3.24 & 4.5 & 3.15 \\
$\mathrm{SO}_{3}$ & 0.10 & 1.20 & 3.10 & \\
\hline
\end{tabular}

The composition difference of raw materials and the activation method, which uses a strong alkaline $(\mathrm{NaOH}$ or $\mathrm{KOH})$ solution combined with the water glass $\left(\mathrm{Na}_{2} \mathrm{SiO}_{3}\right)$ solution, cause a different microstructure between AAMs and OPC concrete. The hydration product of OPC concrete is already well studied, which is known as calcium silicate hydrate (C-S-H) and calcium hydroxide ( $\mathrm{CH})$ [43]. However, AAMs have two microstructure types [3], i.e., the high-calcium type (slag), C-A-S-H; the low-calcium type (class F fly ash), N-A-S-H. The 2D schematic among these three microstructures is shown in Figure 1.
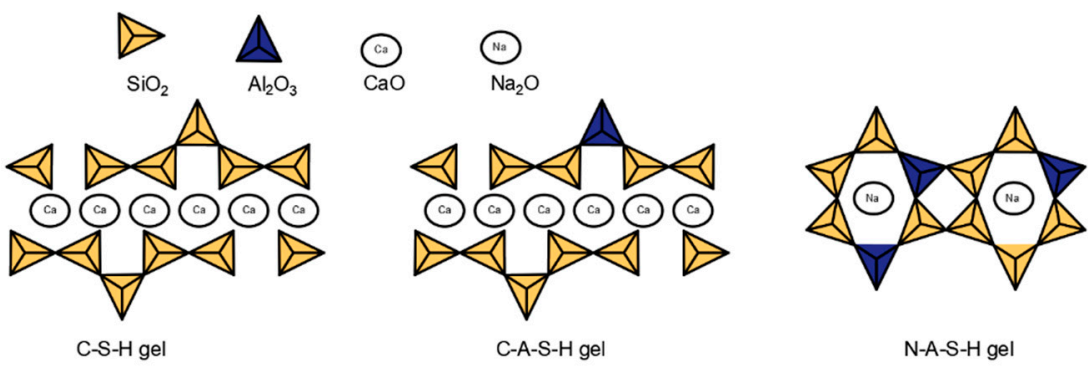

Figure 1. Two-dimensional schematic of C-S-H, C-A-S-H and N-A-S-H.

In Figure 1, it can be seen that C-S-H and C-A-S-H have the similar microstructure except that silicate tetrahedra in C-A-S-H is partially replaced by aluminium tetrahedra [44]. This is consistent with slag and OPC having similar compositions in raw materials, as shown in Table 1. According to García-Lodeiro et al. [45], the monomer N-A-S-H is more likely a circle shape and the silicate tetrahedron is also partially replaced by the aluminium tetrahedron. From Provis et al. [46], the C-A-S-H has more tortuosity and denser pore structures than the other two, while N-A-S-H is the more porous microstructure. In addition, the curing environment, i.e., curing temperature, affects the formation of microstructure, hence the compressive strength, as shown in Figure 2. It can be observed that the peak compressive strength is at $75^{\circ} \mathrm{C}$ and the trend is that the compressive strength first increases with temperature and then decreases. Enhancing the temperature promotes the formation of AAM's microstructure but very high temperature inhibits it and causes moisture vapor to escape from concrete, affecting the reaction environment of concrete paste $[47,48]$. Moreover, the compressive strength increases with curing time, increasing under the same temperature, as demonstrated in Figure 2. Fang et al. [49] investigated the effect of different parameters such as curing time on the engineering properties of AAS. They concluded that continuous curing after 28 days can significantly improve the engineering properties of AAS. Additional to compressive strength, AAMs with curing at 
elevated temperature could reduce the volume of voids and the average pore size, which decreases the permeability of AAMs [50-53].



Figure 2. The evolution of compressive strength of alkali-activated class $C$ fly ash with temperature, reprinted from ref. [9].

\subsection{Carbonation}

By decreasing the concrete $\mathrm{pH}$ through dissolved carbon dioxide $\left(\mathrm{CO}_{2}\right)$, carbonation is one of the main corrosion mechanisms of concrete, which leads to the reinforcement passive layer depassivation and the initiation of corrosion. AAMs have less carbonation resistance than OPC concrete regarding the end product $[12,54]$. The reason is that AAMs do not contain or contain little portlandite [55] in pore solutions. The portlandite provides a buffer effect $[12,56]$ that delays the advancement of $\mathrm{CO}_{2}$ and maintains a stable and high alkalinity environment for steel passivation. However, the alkalinity of AAMs depends on the concentration of the activated solution that is used [54]. Once the alkali of pore solutions is consumed by the dissolved $\mathrm{CO}_{2}$, AAMs can no longer maintain a high alkaline environment that maintains steel passivation [57].

Due to this characteristic, AAMs are more susceptible to $\mathrm{CO}_{2}$ deterioration than OPC concrete. Aperador et al. [12] found AAS has the lower carbonation resistance than OPC concrete at 3\% $\mathrm{CO}_{2}$ concentration. Bernal et al. [54] also concluded that AAMs show a more rapid carbonation rate than OPC concrete under 3\% $\mathrm{CO}_{2}$. Bernal et al. [18] studied the effect of $\mathrm{RH}$ (relative humidity) and the concentration of $\mathrm{CO}_{2}$ on the carbonation behaviour of AAMs. The partially saturated moisture condition could accelerate the carbonation rate while the saturated moisture condition could decrease the carbonation rate [58-60]. Furthermore, they suggested that $1 \% \mathrm{CO}_{2}$ should be used for accelerated carbonation other than higher concentration $\mathrm{CO}_{2}$ [13]. Babaee et al. [19] studied the carbonation behaviour of blended fly ash and slag AAMs at $1 \% \mathrm{CO}_{2}$ concentration for 500 days. They noticed the formation of bicarbonates was greater than carbonates at high $\mathrm{CO}_{2}$ concentration that decreased the $\mathrm{pH}$ below 10, which was also consistent with findings in [17]. This can be attributed to the equilibria system of natron/nahcolite (carbonates/bicarbonates), i.e., $\mathrm{NaCO}_{3}-\mathrm{NaHCO}_{3}-\mathrm{H}_{2} \mathrm{O}[24]$ in pore solutions:

$$
\mathrm{CO}_{3}^{2-}+\mathrm{H}_{2} \mathrm{O} \rightleftharpoons \mathrm{HCO}_{3}^{-}+\mathrm{OH}^{-}
$$

However, the detailed transformation relation between carbonates and bicarbonates in AAMs remains unclear. A general trend is shown in Figure 3. It can be observed that increasing the $\mathrm{CO}_{2}$ concentration leads to natron decrease and nahcolite increase. The 
natron phase can maintain concrete $\mathrm{pH}$ over 10 while the nahcolite phase can cause $\mathrm{pH}$ to rapidly drop $[19,24]$.

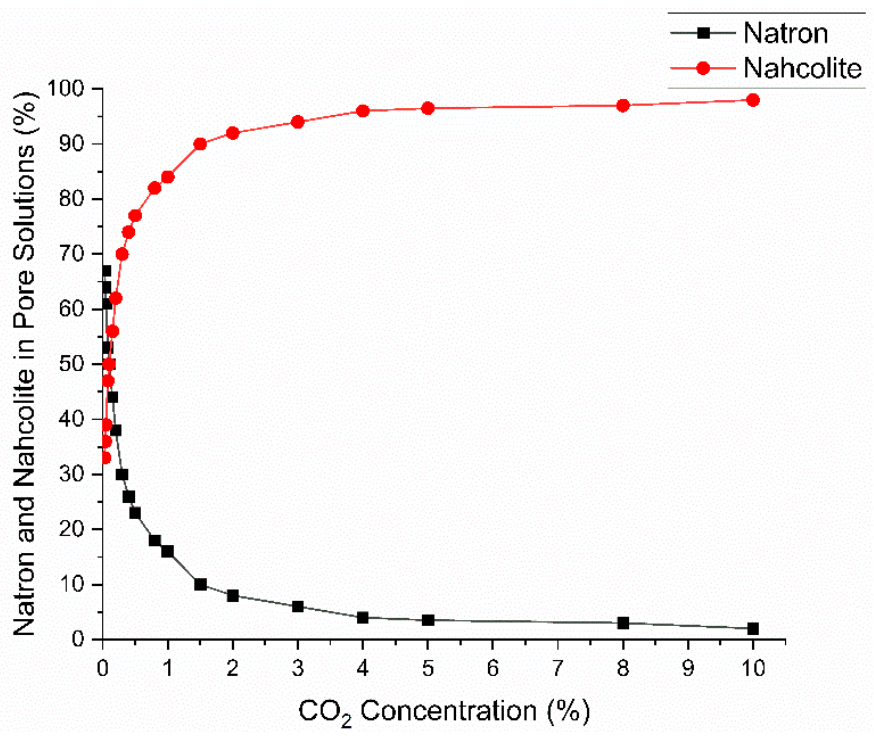

Figure 3. The trend of natron and nahcolite with increasing $\mathrm{CO}_{2}$ concentration, reprinted from ref. [17].

In the natural carbonation environment, the $\mathrm{CO}_{2}$ concentration is about $0.03 \%$ [12]; therefore, natron plays the dominant role. $\mathrm{Xu}$ et al. [61] characterised 35-year-old slagbased AAMs under natural exposure; the concrete remained sound and the strength increased. Bernal et al. [16] researched the properties of AAS that was exposed to the natural environment for 7 years. The carbonation depth of $400 \mathrm{~kg} / \mathrm{m}^{3}$ AAS concrete after 7 years was about $17 \mathrm{~mm}$ while the predicted value from the accelerated carbonation test under $1 \% \mathrm{CO}_{2}$ environment was $20.83 \mathrm{~mm}$. Pasupathy et al. [62] characterised 8-year AAMs (blended of slag and fly ash) that were exposed to the natural environment, noticing that the low $\mathrm{Ca} / \mathrm{Si}$ ratio led to low carbonation resistance comparable to OPC concrete.

It is also noted the chemical composition of raw materials and pore solutions also affect the carbonation resistance of AAMs. Increasing $\mathrm{MgO}$ content in the AAS mixture helps form the hydrotalcite-like phase that is a layered double hydroxide (LDH) structure in AAS paste, which has the ability to decrease the carbonation rate $[21,63,64]$. The dosage of alkali solution and silicate modulus to be used also plays an important role in carbonation resistance of AAS [65]; increasing both promotes dissolution of slag grains and porosity reduction. However, a very high dosage of alkali solution increases the risk of efflorescence of AAMs [19].

\subsection{Chloride Penetration}

In many cases, unlike the carbonation cases that AAMs have low carbonation resistance, AAMs were reported to have better or comparable chloride resistance to OPC concrete, as shown in Figure 4. In Figure 4, AAMs have the lowest chloride penetration depth at both 28 - and 90 -day curing, especially the $100 \%$ slag AAMs. The next is blended slag/fly ash with a binder ratio of $75 \% / 25 \%$. The AAM sample with the ratio of $50 \% / 50 \%$ has a slightly greater chloride penetration depth than the other two at 28-day curing, but is lower after 90 days. The OPC has the highest chloride penetration depth for both 28 days and 90 days. 


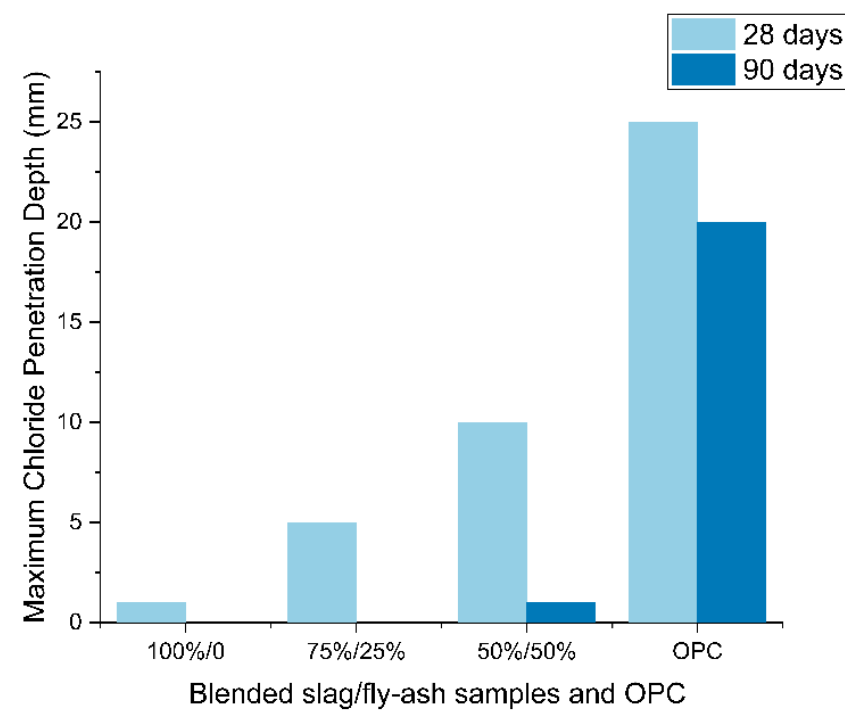

Figure 4. Maximum chloride penetration depth after curing for 28 and 90 days as a function of slag/fly-ash ratio, reprinted from ref. [66].

For the high-calcium AAMs, Bouteiller et al. [23] found the slag-dominated concrete (blended OPC and slag) has better chloride resistance than OPC concrete alone, which was mainly achieved by the tortuosity and dense microstructure of C-A-S-H. Criado and Provis [31] assessed the corrosion behaviour of reinforcement embedded in AAS mortars under 9-month exposure to a chloride-rich environment, and found the AAS mortar has higher chloride resistance than OPC mortar. Babaee and Castel [67] found an increase of slag content over $50 \%$ in blended slag and fly-ash AAMs mortar would efficiently decrease the chloride diffusion coefficient compared to AAFA mortar.

Focusing on the secondary binder phases in AAMs, the form of AFm phase and the hydrotalcite-like phase [68-70] in high-calcium AAMs all contribute to chloride binding capacity. These mineral phases delay the penetration of chloride ions in addition to the mechanism provided by the C-A-S-H microstructure. For these phases, the $\mathrm{Al}_{2} \mathrm{O}_{3}$ and $\mathrm{MgO}$ play an important role, i.e., (1) the amount of hydrotalcite-like phase increases with the increase of $\mathrm{MgO}$ content (high $\mathrm{Mg} / \mathrm{Al}$ ratio), which results in restraining $\mathrm{Al}$ incorporation in C-A-S-H [69]; (2) contrary to $\mathrm{MgO}$, increasing $\mathrm{Al}_{2} \mathrm{O}_{3}$ content (low $\mathrm{Mg} / \mathrm{Al}$ ratio) promotes the formation of C-A-S-H and AFm phases, decreasing the hydrotalcite-like phase [71].

For the low-calcium AAMs, e.g., the class F fly ash, Miranda et al. [27] stated the reinforcement embedded in AAFA mortar has similar passivation behaviour to OPC mortar. Kupwade-Patil and Allouche [72] examined the chloride-induced corrosion of reinforcement embedded in AAFA concrete. AAFA concrete has a lower diffusion coefficient and less corrosion product than OPC concrete after a 12-month cyclic wetting and drying chloride corrosion test. Monticelli et al. [73] found the AAFA mortar has a slightly higher protectiveness for embedded reinforcement than OPC mortar when chloride ingress into mortars, even though AAFA mortar has more porosity. As noted in Section 2.2, the characteristic that is more susceptible to carbonation of AAFA leads to the alkalinity of AAFA decrease, which causes depassivation of embedded steel. Therefore, the lower protectiveness to carbonation for embedded steel was afforded by AAFA [74]. Noushini et al. [75] found a more homogenous matrix formed in AAFA concrete, which was achieved by increasing temperature; however, AAFA concrete has lower chloride resistance compared to OPC concrete. This may be due to the polycondensation [76] of AAMs that leads to increased microcracks, which accelerates the ingress of chloride ions.

For the blended high- and low-calcium AAMs, the properties of end products depend on the dominant precursor materials. Babaee and Castel [67] studied the chloride diffusivity, chloride threshold, and corrosion imitation of blended fly ash and GGBS (granulated blastfurnace slag) with the ratios $75 \% / 25 \%, 50 \% / 50 \%$ and $25 \% / 75 \%$. Increasing the GGBS 
content decreases the chloride permeability and diffusivity due to the formation of C-A-S$\mathrm{H}$, which is consistent with [66]. In addition, they found the higher alkali concentration will inhibit the dissolution of calcium content by the calcium hydroxide layer formed around slag particles, which increases the porosity of the matrix paste. Furthermore, the higher alkali concentration may lead to the risk of leaching in the matrix pastes [77].

\subsection{Combined Corrosion Process of Carbonation and Chloride Ingress}

As discussed, carbonation and chloride ingress can each induce corrosion of AAM structures. In some applications, however, these two mechanisms can work together, which might intensify the corrosion extent. In recent years, the combined effect of carbonation and chloride ingress on AAMs has attracted research effort. In some literature [28,78-81], the effect of carbonation on the chloride binding capacity of AAMs concrete or OPC concrete blended with AAMs was investigated, and it was found carbonation decreased the chloride binding capacity. In other words, carbonation of AAMs concrete will accelerate and deepen the chloride penetration of concrete.

Chang [78] investigated the chloride binding capacity of cement paste that blended OPC and AAMs, under three conditions: (1) sample suffered carbonation first and then immersed in chloride solution, (2) sample immersed in chloride solution and then suffered carbonation and (3) 3.5\% NaCl solution was added to sample during the cast and then suffered carbonation. The sample under condition (3) had a higher bound chloride content because more Friedel's salt was formed than the other two conditions during the carbonation. The binding capacity under three conditions was zero after the samples were fully carbonated. Khan et al. [28] investigated the role of hydrotalcite in AAS concrete and they found that the hydrotalcite played a significant role in the chloride binding capacity of AAS concrete, and it was almost without impairment under the competition adsorption of carbonates. Although the hydrotalcite does not impair by carbonates, the presence of carbonates decreases its chloride binding capacity because carbonates occupy the middle layer of the LDH structure [79]. Shi et al. [57] investigated the long-term corrosion resistance performance of AAS mortar and OPC mortar under a marine environment. They found macrocracks were induced due to drying shrinkage of AAS mortar after long-term atmospheric exposure under a marine environment, which would accelerate the corrosion process and yield lower corrosion resistance than OPC mortar.

However, most cases discussed above used a high $\mathrm{CO}_{2}$ concentration to accelerate the carbonation process, which was unreliable to predict the real service life under combined natural carbonation and chloride ingress of AAMs. Due to limited data, the long-term performance of AAMs at the structural level that suffers natural carbonation and chloride ingress is very unclear.

\section{Steel-AAM Concrete Interface}

For the purpose of using AAMs in practice, understanding the corrosion mechanism at the steel-concrete/mortar interface of AAMs is important, which helps to predict the service life of AAM structures. Shi et al. [82] investigated the chloride-induced corrosion behaviour of novel alloy steel and low-carbon steel in OPC and AAS mortars. They found a less protective passive layer was formed on both types of steel in AAS mortars; however, compared to OPC mortars, a denser and compact interfacial zone was formed at the steelmortar interface. Through extracted solutions that were from OPC and AAS, which were used for studying the passivation behaviour and chloride corrosion resistance of steel, Shi et al. [82] found low-carbon steel in AAS samples had higher chloride resistance than in OPC samples. It may be due to the gel-like substance that was formed on the steel surface. However, an opposite phenomenon to low-carbon steel in [83], which was the corrosion of 2304 duplex stainless steel, was higher in AAS mortar than OPC mortar due to the formation of an unstable passive layer, as shown in [84]. The type of steel and its properties [85] may have a different effect on corrosion mechanisms in AAS mortars. Chen et al. [86] characterised the composition of the passive layer on the steel surface 
through simulated pore solution of AAFA. A bilayer structure of iron (FeOOH-rich outer layer and FeO-rich inner layer) and a firm layer of the zeolite-like structure were formed on the steel surface. This is consistent with [32]; the outer layer $(\mathrm{FeOOH})$ plays an important role in the aspect of initiation of pitting corrosion, and needs further investigation. In addition, Mundra et al. [32] suggested using $\left[\mathrm{Cl}^{-}\right] /\left[\mathrm{OH}^{-}\right]^{3}$ to define the critical chloride for the initiation of pitting corrosion on the outer passive film layer.

You et al. [87] examined the corrosion behaviour of low-carbon steel reinforcement embedded in different AAMs mortars (the AAS and the alkali-activated slag-steel slag) under a simulated marine environment considering atmospheric zone, tidal zone and submerged zone. Higher deformation of AAMs and more cracks at the steel-mortar interface under a simulated tidal zone were observed after the exposure for 480 days. Furthermore, they found the corrosion mechanism of embedded steel in AAMs is different from OPC mortars, i.e., the typical pitting corrosion cannot be observed in AAMs. Furthermore, a loose interface at the steel-mortar interface of AAMs is observed [87]. This interface is related to the double action of sulphide content in AAMs that consumes oxygen at the steel-mortar interface and reacted with sulphide products on the steel interface [88], which inhibits the formation of the passive layer. Mangat et al. [89] investigated the durability of AAS concrete and OPC concrete under the aggressive environment for up to 1750 days; they found the $\mathrm{SO}_{3}^{2-}$ content at the steel-AAS concrete interface is up to $80 \%$ higher than OPC concrete. However, the corrosion resistance mechanism of this sulphide film on the steel surface remains unclear.

\section{Electrochemical Measurement}

\subsection{Half-Cell Potential}

Half-cell potential is the most commonly used electrochemical measurement for monitoring the corrosion state or potential of the reinforced concrete structures. This technique rapidly and nondestructively detects and locates the localised corrosion of reinforced concrete structures [90]. Using this method, the rebar acts as the working electrode (WE) together with a suitable reference electrode (RE), such as a copper/copper sulphide electrode (CSE) [91], a saturated calomel electrode (SCE) [35] or a silver/silver chloride electrode $(\mathrm{Ag} / \mathrm{AgCl})$ that is filled with different concentrations of potassium chloride ( $\mathrm{KCl})$, e.g., $3 \mathrm{M} \mathrm{KCl}$ [31], as shown in Figure 5. The corrosion potential ( $\mathrm{E}_{\mathrm{corr}}$ ) map of concrete can be drawn from the measured data, which is then used to find the localised corrosion [92].

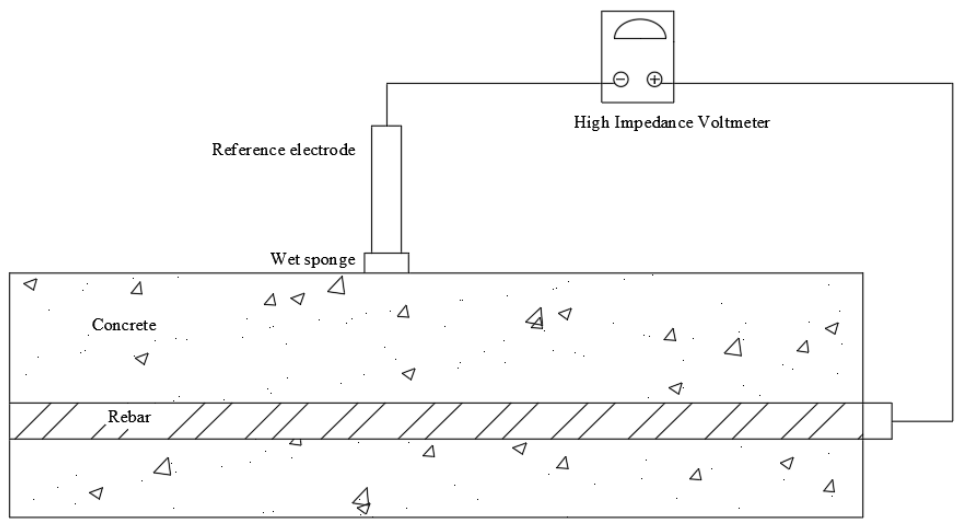

Figure 5. Half-cell potential method.

Table 2 lists the determination criteria for the corrosion probability of steel embedded in concrete, based on the reference electrode above, according to ASTM C876 [34]. 
Table 2. The half-cell potential and related corrosion risk of steel embedded in concrete [34].

\begin{tabular}{cccc}
\hline (mV vs. CSE) & (mV vs. SCE) & (mV vs. Ag/AgCl, 3 M KCL) & Corrosion Probability \\
\hline$E_{\text {corr }}>-200$ & $E_{\text {corr }}>-127$ & $E_{\text {corr }}>-96$ & Low probability (10\% corrosion risk) \\
$-200<E_{\text {corr }}<-350$ & $-127<E_{\text {corr }}<-277$ & $-96<E_{\text {corr }}<-246$ & Intermediate condition \\
$E_{\text {corr }}<-350$ & $E_{\text {corr }}<-277$ & $E_{\text {corr }}<-246$ & High probability (90\% corrosion risk) \\
\hline
\end{tabular}

Commonly, the determination criterion was reported as not suitable for AAMs because more negative values $\left(\mathrm{E}_{\mathrm{corr}}\right)$ compared with OPC concrete were found for the corrosion initiation, which indicated a $90 \%$ probability of corrosion. However, the rebar after extraction showed no evidence of corrosion [30,91]. Table 3 lists recent studies on the half-cell potential of AAMs based on different precursor materials.

It can be observed from Table 3 that the half-cell potential value from chloridecontaminated samples is generally more negative, which means all samples suffer severe corrosion risk according to Table 2. However, there is no evidence of pits or corrosion products that can be visually observed on rebars [30,93] except for samples in [94]. The difference of the distinct behaviour is attributed to the precursor materials in the formerslag in raw materials, which forms a dense microstructure and hydrotalcite-like phase. The latter uses low-calcium fly ash as the precursor material, of which the microstructure is more porous and has less chloride binding capacity concerning the end product. The negative value of the former may be due to the oxidation reaction of sulphide supplied by slag [93], while the latter is probably due to the chloride enrichment in the steel-AAM interface. For samples not contaminated by chloride, the half-cell potential values fall into two risk categories: one is linked to the severe corrosion risk category $[33,35,73]$ and others belong to the intermediate corrosion condition [27,30,93-95]. The pre-dried environment [35] and low relative humidity curing environment [73] enhances the capillary suction and the diffusion effect in concrete pore structures that increase the rate of chloride ingress into concrete; too high a concentration of chloride salts, i.e., samples immersed in $5 \%$ sodium chloride solution [33], leads to a concentration gradient growth that increases the rate of chloride ingress into concrete.

In summary, the chloride contaminated during AAMs concrete cast in, and pretreatment environment and curing conditions (i.e., pre-dried, low relative humidity curing), etc., leads to the half-cell potential values of concrete that are listed in the severe corrosion risk zone (Table 2). However, it does not mean the concrete will suffer corrosion; therefore, the determination criteria of corrosion from OPC concrete may not be suitable for AAMs.

Table 3. Half-cell potential of AAMs [27,30,31,33,35,73,94-96].

\begin{tabular}{|c|c|c|c|}
\hline \multirow[b]{2}{*}{ Reference } & \multirow[b]{2}{*}{ Material } & \multicolumn{2}{|c|}{ Half-Cell Potential ( $\left.E_{\text {corr }}\right)$} \\
\hline & & Chloride Contaminated Sample & $\begin{array}{l}\text { Non-Chloride Contaminated } \\
\text { Sample }\end{array}$ \\
\hline [95] & OPC + Metakaolin & $\mathrm{N} / \mathrm{A}$ & Around $-300 \mathrm{mV} V_{\mathrm{SCE}}$ \\
\hline [27] & Fly ash & Around $-600 \mathrm{mV}_{\mathrm{SCE}}$ & $-150 \mathrm{mV}_{\mathrm{SCE}}$ to $-200 \mathrm{mV}_{\mathrm{SCE}}$ \\
\hline [73] & Fly ash & $\mathrm{N} / \mathrm{A}$ & $-550 \mathrm{mV}_{\mathrm{SCE}}$ to $-600 \mathrm{mV}_{\mathrm{SCE}}$ \\
\hline$[35]$ & Fly ash + Slag & $\mathrm{N} / \mathrm{A}$ & $-550 \mathrm{mV}_{\mathrm{SCE}}$ to $-650 \mathrm{mV}_{\mathrm{SCE}}$ \\
\hline [30] & Fly ash + Slag & $-600 \mathrm{mV}_{\mathrm{SCE}}$ to $-700 \mathrm{mV}_{\mathrm{SCE}}$ & $-200 \mathrm{mV}_{\mathrm{SCE}}$ to $-400 \mathrm{mV}_{\mathrm{SCE}}$ \\
\hline$[31]$ & Slag & Around $-650 \mathrm{mV}_{\mathrm{AgCl}}$ & Around $-100 \mathrm{mV}_{\mathrm{AgCl}}$ \\
\hline [94] & Fly ash & $-400 \mathrm{mV}_{\mathrm{CSE}}$ to $-600 \mathrm{mV}_{\mathrm{CSE}}$ & Around $-150 \mathrm{mV}_{\mathrm{CSE}}$ \\
\hline [33] & Natural pozzolan & $\mathrm{N} / \mathrm{A}$ & $-300 \mathrm{mV}_{\mathrm{SCE}}$ to $-600 \mathrm{mV}_{\mathrm{SCE}}$ \\
\hline [96] & $\begin{array}{c}\text { Slag + Palm oil fuel ash + Rice husk ash } \\
\text { Slag + fly ash + Rice husk ash }\end{array}$ & $\mathrm{N} / \mathrm{A}$ & $-230 \mathrm{mV}_{\mathrm{CSE}}$ to $-500 \mathrm{mV}_{\mathrm{CSE}}$ \\
\hline
\end{tabular}

\subsection{Linear Polarization Resistance and Tafel Polarization}

Linear polarization resistance (LPR) is a rapid and nondestructive technique for monitoring the corrosion rate of reinforced concrete. It generally uses a potentiostat with 
a three-electrode system: rebar acts as the WE, a counter electrode (CE) such as titanium mesh, and both are combined with a RE, as shown in Figure 6.

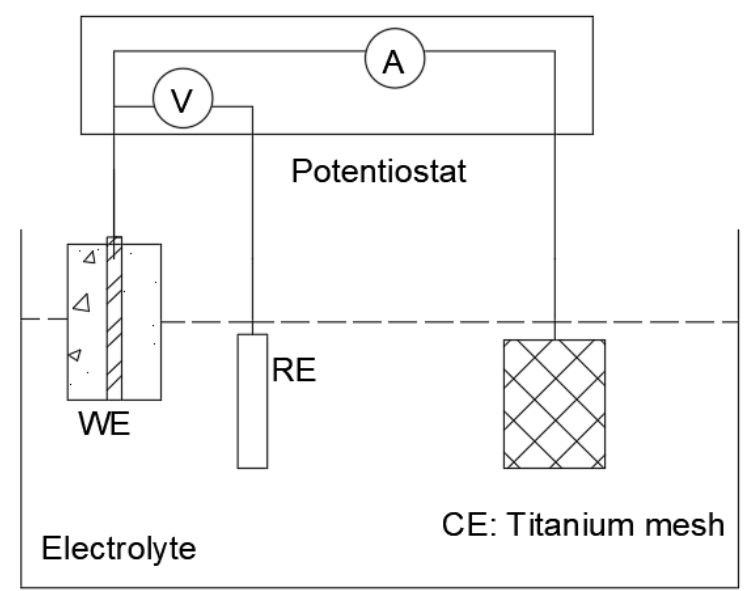

Figure 6. Linear polarization resistance system.

From this technique, the slope (polarization resistance $R_{p}$ ) of the polarization curve can be obtained from a potential-current plot, i.e.,

$$
\mathrm{R}_{\mathrm{P}}=\left(\frac{\Delta \mathrm{E}}{\Delta \mathrm{i}}\right)_{\Delta \mathrm{E} \longrightarrow 0}
$$

where $\mathrm{i}$ is current density and $\Delta \mathrm{E}$ is the corrosion potential difference that is obtained from the open-circuit potential method [29]. Then, combining with the Tafel extrapolation method [97], the corrosion current density $i_{\text {corr }}$ is obtained from Tafel constant $B$ and $R_{p}$,

$$
\begin{gathered}
\mathrm{i}_{\text {corr }}=\frac{\mathrm{B}}{\mathrm{R}_{\mathrm{p}}} \\
\mathrm{B}=\frac{\mathrm{b}_{\mathrm{a}} \mathrm{b}_{\mathrm{c}}}{2.303\left(\mathrm{~b}_{\mathrm{a}}+\mathrm{b}_{\mathrm{c}}\right)}
\end{gathered}
$$

where $b_{a}$ and $b_{c}$ is the anodic and cathodic Tafel slope, respectively. Based on large experimental data, the empirical value of Tafel constant B for OPC concrete is 52 and $26 \mathrm{mV}$ for passive and active samples, respectively [98]. However, these two values are affected by different parameters [35,99-102], for example, the conductivity of electrolyte, which depends on the saturation and various ions in pore solution.

For AAMs, the empirical value from OPC concrete may no longer be suitable because the composition and pore solution chemistry are different from OPC concrete. Babaee and Castel [35] calculated Tafel constant B values for blended fly ash and slag AAMs concrete and found they were 13 20 mV for passive samples and $45 \sim 58 \mathrm{mV}$ for active samples. They stated that using the empirical value may underestimate the corrosion rate. However, there were different findings on Tafel constant B for active samples- the Tafel constant B was not listed in this interval $[20,103,104]$. A comparison of Tafel constant B values is shown in Table 4. Robayo-Salazar et al. [20] investigated the corrosion performance of blended natural pozzolans and slag AAMs concrete under $1 \% \mathrm{CO}_{2}$ for 360 days. They found Tafel constant $B$ values for the passive sample was $19.9 \mathrm{mV}$ (sample at 0 days) and the active sample was $16.8 \mathrm{mV}$ (sample at 360 days). Aguirre-Guerrero et al. [104] investigated the corrosion performance of blended natural pozzolan and slag AAMs concrete samples that were exposed to chlorides. From 600 days of wet-dry cycles and 3.5\% saltwater immersion, they found the Tafel constant B was $20 \mathrm{mV}$ at 0 days and $17 \mathrm{mV}$ at 600 days. ValenciaSaavedra et al. [103] studied the carbonation behaviour of blended fly ash and slag concrete and fly ash and OPC concrete under $1 \% \mathrm{CO}_{2}$. They found the Tafel constant $\mathrm{B}$ value for 
active samples calculated from the test results were much smaller than the values in [35], as shown in Table 4.

Table 4. Comparison of Tafel constant value between OPC and AAMs $[20,35,98,103,104]$.

\begin{tabular}{ccc}
\hline Concrete Type & Passive Samples (mV) & Active Samples (mV) \\
\hline Empirical value (OPC) [98] & 52 & 26 \\
Fly ash + Slag [35] & $13 \sim 20$ & $45 \sim 58$ \\
Natural pozzolans + Slag [20] & 19.9 & 16.8 \\
Natural pozzolans + Slag [104] & 20 & 17 \\
Fly ash + OPC [103] & 27.2 & 15.3 \\
Fly ash + Slag [103] & 24 & 18.4 \\
\hline
\end{tabular}

From Table 4, it can be seen that the Tafel constant B values of AAMs concrete are obviously different from OPC concrete. The B values of passive samples remained consistent around $20 \mathrm{mV}$ except for blended fly ash and OPC concrete. In contrast to passive samples, $B$ values for active samples are controversial; the values from [35] are much larger than others $[20,98,103,104]$. However, it is difficult to judge based on existing datasets; more research is definitely needed. Therefore, we believe this topic is still open for discussion.

\section{Research Gaps}

Alkali-activated concrete structures underperform in the accelerated carbonation environment. However, the natural carbonation environment yields higher corrosion resistance for alkali-activated concretes. Therefore, the results from the accelerated carbonation tests would need to be adjusted before they can be used. Using a high concentration of carbon dioxide (i.e., over 1\%) will return different results than the natural carbonation. Portlandite content is a key in delaying carbonation, which provides a buffer effect for the ingress of $\mathrm{CO}_{2}$. The chloride resistance mainly depends on the tortuosity and fine pores of C-A-S-H or N-A-S-H, which are affected by the precursor material compositions, binder ratios, concentration of the activation solution, etc. The effect of each parameter has been well understood; however, how are carbonation and chloride ingress affected or controlled in a systematic manner? In other words, how these parameters may work together to affect the long-term performance and, in particular, the corrosion resistance on the structural level, is remains unclear.

The corrosion mechanism on the steel-concrete interface of AAMs is not yet well understood. The passivation degree affects the corrosion resistance of the embedded rebar; however, the reduction effect of sulphide species of precursor material will partially consume the oxygen content at the steel-concrete interface, which leads to the low degree of passivation. In addition, the thickness of the steel-concrete interface of AAMs is reported to be less than OPC concrete. Therefore, once corrosion is initiated, will the accumulation of corrosion products and the time for the concrete cover to crack be different for OPC or likely faster? The evolution of corrosion and subsequent cracking is not yet known and needs further study.

Half-cell potential and linear polarization resistance methods are commonly used either on-site or in the laboratory to test the corrosion extent or rate of the concrete structures. The difference in the composition of precursor materials and the activation method leads to the unique properties of alkali-activated concrete. Previously oven-dried samples or additional chlorides, used to accelerate the corrosion process, generally cause more negative half-cell potentials. For samples that do not contain chloride and for exposure to a non-chloride environment, the half-cell potential value is generally stable [31,91]. Furthermore, the Tafel constant and Tafel slope of the alkali-activated concrete are different from the OPC concrete and hence, the guidance values and corrosion thresholds for OPC concrete are no longer suitable. New data and criteria are needed in this regard. 


\section{Conclusions}

In this paper, the corrosion mechanisms for reinforced alkali-activated concrete structures were reviewed. The differences for carbonation and chloride ingress in the alkaliactivated concrete, in comparison to OPC, were first discussed. The steel-alkali-activated concrete interface was then focused on and discussed concerning its physical and chemical characteristics. The difference in measuring the corrosion potential and corrosion rates for this new material with reference to OPC concrete was also reviewed. Research gaps and future research needs were finally proposed. The following presents some specific concluding remarks:

- AAMs exhibit a good chloride resistance property but poorer carbonation resistance, in comparison with OPC. The mechanisms are well understood, especially on the material level, e.g., chloride binding, $\mathrm{CH}$ reaction with $\mathrm{CO}_{2}$, formation of new microstructure, etc. However, the long-term performance of the alkali-activated concrete structure under the combined carbonation and chloride ingress, and the underlying mechanism for the combined effect, need to be investigated.

- The interfacial properties of alkali-activated concrete are different from OPC concrete, including the physical and chemical aspects. This results in different corrosion accumulation and evolution. This is much less clear than the carbonation and chloride ingress and warrants further research.

- The current criteria for judging corrosion potential and measuring corrosion rates for OPC concrete cannot be directly used for the alkali-activated concrete structures. In some cases, the results are even controversial. To avoid inaccurate determination of corrosion state, new methods, perhaps, and new experimental data are urgently needed for application to alkali-activated concrete structures.

- In the context of a carbon neutral or net zero target in most countries, using alkaliactivated waste materials to fully or partially replace the ordinary concrete seems a promising approach. In terms of known properties and mechanisms, the alkaliactivated concrete structures may well be used in various infrastructure applications, including high corrosive marine environments.

Author Contributions: Conceptualization, S.Y.; methodology, F.Z., X.X. and S.Y.; formal analysis, F.Z.; writing, F.Z., X.X. and S.Y. All authors have read and agreed to the published version of the manuscript.

Funding: This research received no external funding.

Institutional Review Board Statement: Not applicable.

Informed Consent Statement: Not applicable.

Data Availability Statement: Data available from the corresponding author upon request.

Conflicts of Interest: The authors declare no conflict of interest.

\section{References}

1. Ali, M.; Saidur, R.; Hossain, M. A Review on Emission Analysis in Cement Industries. Renew. Sustain. Energy Rev. 2011, 15, 2252-2261. [CrossRef]

2. Koch, G.; Brongers, M.; Thompson, N.; Virmani, Y.P.; Payer, J. Corrosion Cost and Preventive Strategies in the United States; Federal Highway Administration: Washington, DC, USA, 2001.

3. Provis, J.L. Geopolymers and other Alkali Activated Materials: Why, How, and What? Mater. Struct. 2013, 47, 11-25. [CrossRef]

4. Awoyera, P.; Adesina, A. A Critical Review on Application of Alkali Activated Slag as a Sustainable Composite Binder. Case Stud. Constr. Mater. 2019, 11, e00268. [CrossRef]

5. Pulselli, R.; Simoncini, E.; Ridolfi, R.; Bastianoni, S. Specific Emergy of Cement and Concrete: An Energy-Based Appraisal of Building Materials and their Transport. Ecol. Indic. 2008, 8, 647-656. [CrossRef]

6. Yang, K.-H.; Song, J.-K.; Song, K.-I. Assessment of $\mathrm{CO}_{2}$ Reduction of Alkali-Activated Concrete. J. Clean. Prod. 2013, 39, 265-272. [CrossRef]

7. Duxson, P.; Provis, J.; Lukey, G.C.; Van Deventer, J.S. The Role of Inorganic Polymer Technology in the Development of ‘Green Concrete'. Cem. Concr. Res. 2007, 37, 1590-1597. [CrossRef] 
8. Duxson, P.; Provis, J.; Lukey, G.C.; Mallicoat, S.W.; Kriven, W.M.; van Deventer, J.S. Understanding the Relationship between Geopolymer Composition, Microstructure and Mechanical Properties. Colloids Surf. A Physicochem. Eng. Asp. 2005, $269,47-58$. [CrossRef]

9. Guo, X.; Shi, H.; Dick, W.A. Compressive Strength and Microstructural Characteristics of Class C Fly Ash Geopolymer. Cem. Concr. Compos. 2010, 32, 142-147. [CrossRef]

10. Mo, K.H.; Alengaram, U.J.; Jumaat, M.Z. Structural Performance of Reinforced Geopolymer Concrete Members: A review. Constr. Build. Mater. 2016, 120, 251-264. [CrossRef]

11. Sofi, M.; van Deventer, J.; Mendis, P.; Lukey, G. Engineering Properties of Inorganic Polymer Concretes (IPCs). Cem. Concr. Res. 2007, 37, 251-257. [CrossRef]

12. Aperador, W.; De Gutierrez, R.M.; Bastidas, D.M. Steel Corrosion Behaviour in Carbonated Alkali-Activated Slag Concrete. Corros. Sci. 2009, 51, 2027-2033. [CrossRef]

13. Bernal, A.S.; Provis, J.; Walkley, B.; Nicolas, R.S.; Gehman, J.D.; Brice, D.G.; Kilcullen, A.R.; Duxson, P.; Van Deventer, J.S. Gel Nanostructure in Alkali-Activated Binders Based on Slag and Fly Ash, and Effects of Accelerated Carbonation. Cem. Concr. Res. 2013, 53, 127-144. [CrossRef]

14. Zhao, K.; Liang, Y.; Ji, T.; Lu, Y.; Lin, X. Effect of Activator Types and Concentration of $\mathrm{CO}_{2}$ on the Steel Corrosion in the Carbonated Alkali-Activated Slag Concrete. Constr. Build. Mater. 2020, 262, 120044. [CrossRef]

15. Bakharev, T.; Sanjayan, J.; Cheng, Y.-B. Resistance of Alkali-Activated Slag Concrete to Carbonation. Cem. Concr. Res. 2001, 31, 1277-1283. [CrossRef]

16. Bernal, S.A.; Nicolas, R.S.; Provis, J.; De Gutierrez, R.M.; Van Deventer, J.S.J. Natural carbonation of aged alkali-activated slag concretes. Mater. Struct. 2014, 47, 693-707. [CrossRef]

17. Bernal, S.A.; Provis, J.L.; Brice, D.G.; Kilcullen, A.; Duxson, P.; van Deventer, J.S. Accelerated Carbonation Testing of AlkaliActivated Binders Significantly Underestimates Service Life: The Role of Pore Solution Chemistry. Cem. Concr. Res. 2012, 42, 1317-1326. [CrossRef]

18. Bernal, A.S.; Provis, J.L.; De Gutierrez, R.M.; Van Deventer, J.S.J. Accelerated Carbonation Testing of Alkali-Activated Slag/Metakaolin Blended Concretes: Effect of Exposure Conditions. Mater. Struct. 2015, 48, 653-669. [CrossRef]

19. Babaee, M.; Khan, M.; Castel, A. Passivity of Embedded Reinforcement in Carbonated Low-Calcium Fly Ash-Based Geopolymer Concrete. Cem. Concr. Compos. 2018, 85, 32-43. [CrossRef]

20. Salazar, R.A.R.; Aguirre-Guerrero, A.M.; de Gutiérrez, R.M. Carbonation-Induced Corrosion of Alkali-Activated Binary Concrete Based on Natural Volcanic Pozzolan. Constr. Build. Mater. 2020, 232, 117189. [CrossRef]

21. Khan, M.; Castel, A. Effect of $\mathrm{MgO}$ and $\mathrm{Na}_{2} \mathrm{SiO}_{3}$ on the Carbonation Resistance of Alkali Activated Slag Concrete. Mag. Concr. Res. 2018, 70, 685-692. [CrossRef]

22. Santarsiero, G.; Masi, A.; Picciano, V. Durability of Gerber Saddles in RC Bridges: Analyses and Applications (Musmeci Bridge, Italy). Infrastructures 2021, 6, 25. [CrossRef]

23. Bouteiller, V.; Cremona, C.; Baroghel-Bouny, V.; Maloula, A. Corrosion Initiation of Reinforced Concretes based on Portland or GGBS cements: Chloride Contents and Electrochemical Characterizations Versus Time. Cem. Concr. Res. 2012, 42, $1456-1467$. [CrossRef]

24. Bernal, A.S.; Provis, J.L. Durability of Alkali-Activated Materials: Progress and Perspectives. J. Am. Ceram. Soc. 2014, 97, 997-1008. [CrossRef]

25. Provis, J.; Palomo, A.; Shi, C. Advances in Understanding Alkali-Activated Materials. Cem. Concr. Res. 2015, 78, 110-125. [CrossRef]

26. Choi, Y.-S.; Kim, J.-G.; Lee, K.-M. Corrosion Behavior of Steel Bar Embedded in Fly Ash Concrete. Corros. Sci. 2006, 48, 1733-1745 [CrossRef]

27. Miranda, J.; Fernández-Jiménez, A.; González, J.; Palomo, A. Corrosion Resistance in Activated Fly Ash Mortars. Cem. Concr. Res. 2005, 35, 1210-1217. [CrossRef]

28. Khan, M.; Kayali, O.; Troitzsch, U. Chloride Binding Capacity of Hydrotalcite and the Competition with Carbonates in Ground Granulated Blast Furnace Slag Concrete. Mater. Struct. 2016, 49, 4609-4619. [CrossRef]

29. Andrade, C.; Alonso, C. Test Methods for On-Site Corrosion Rate Measurement of Steel Reinforcement in Concrete by Means of the Polarization Resistance Method. Mater. Struct. 2004, 37, 623-643. [CrossRef]

30. Tennakoon, C.; Shayan, A.; Sanjayan, J.; Xu, A. Chloride Ingress and Steel Corrosion in Geopolymer Concrete Based on Long Term Tests. Mater. Des. 2017, 116, 287-299. [CrossRef]

31. Criado, M.; Provis, J.L. Alkali Activated Slag Mortars Provide High Resistance to Chloride-Induced Corrosion of Steel. Front. Mater. 2018, 5. [CrossRef]

32. Mundra, S.; Criado, M.; Bernal, A.S.; Provis, J.L. Chloride-Induced Corrosion of Steel Rebars in Simulated Pore Solutions of Alkali-Activated Concretes. Cem. Concr. Res. 2017, 100, 385-397. [CrossRef]

33. Ibrahim, M.; Rahman, M.K.; Johari, M.A.M.; Nasir, M.; Oladapo, E.A. Chloride Diffusion and Chloride-Induced Corrosion of Steel Embedded in Natural Pozzolan-Based Alkali Activated Concrete. Constr. Build. Mater. 2020, 262, 120669. [CrossRef]

34. ASTM C876-15, Standard Test Method for Corrosion Potentials of Uncoated Reinforcing Steel in Concrete; ASTM International: West Conshohocken, PA, USA, 2015. [CrossRef] 
35. Babaee, M.; Castel, A. Chloride-Induced Corrosion of Reinforcement in Low-Calcium Fly Ash-Based Geopolymer Concrete. Cem. Concr. Res. 2016, 88, 96-107. [CrossRef]

36. Andrade, C.; Alonso, C. Corrosion Rate Monitoring in the Laboratory and On-Site. Constr. Build. Mater. 1996, 10, 315-328. [CrossRef]

37. Feng, X.; Tang, Y.; Zuo, Y. Influence of Stress on Passive Behaviour of Steel Bars in Concrete Pore Solution. Corros. Sci. 2011, 53, 1304-1311. [CrossRef]

38. Ye, H.; Cartwright, C.; Rajabipour, F.; Radlińska, A. Understanding the Drying Shrinkage Performance of Alkali-Activated Slag Mortars. Cem. Concr. Compos. 2017, 76, 13-24. [CrossRef]

39. Mastali, M.; Kinnunen, P.; Dalvand, A.; Firouz, R.M.; Illikainen, M. Drying Shrinkage in Alkali-Activated Binders-A Critical Review. Constr. Build. Mater. 2018, 190, 533-550. [CrossRef]

40. Juenger, M.; Winnefeld, F.; Provis, J.; Ideker, J. Advances in Alternative Cementitious Binders. Cem. Concr. Res. 2011, 41, 1232-1243. [CrossRef]

41. Shi, W.; Najimi, M.; Shafei, B. Reinforcement Corrosion and Transport of Water and Chloride Ions in Shrinkage-Compensating Cement Concretes. Cem. Concr. Res. 2020, 135, 106121. [CrossRef]

42. ASTM C618-19, Standard Specification for Coal Fly Ash and Raw or Calcined Natural Pozzolan for Use in Concrete; ASTM International: West Conshohocken, PA, USA, 2019. [CrossRef]

43. Bernal, A.S.; DE Gutierrez, R.M.; Pedraza, A.L.; Provis, J.; Rodriguez, E.; Delvasto, S. Effect of Binder Content on the Performance of Alkali-Activated Slag Concretes. Cem. Concr. Res. 2011, 41, 1-8. [CrossRef]

44. Provis, J.L.; Bernal, S.A. Geopolymers and Related Alkali-Activated Materials. Annu. Rev. Mater. Res. 2014, 44, 299-327. [CrossRef]

45. García-Lodeiro, I.; Fernández-Jiménez, A.; Palomo, A. Variation in Hybrid Cements Over Time. Alkaline Activation of Fly Ash-Portland Cement Blends. Cem. Concr. Res. 2013, 52, 112-122. [CrossRef]

46. Provis, J.; Myers, R.; White, C.; Rose, V.; van Deventer, J.S. X-ray Microtomography Shows Pore Structure and Tortuosity in Alkali-Activated Binders. Cem. Concr. Res. 2012, 42, 855-864. [CrossRef]

47. Sindhunata; van Deventer, J.S.J.; Lukey, G.C.; Xu, H. Effect of Curing Temperature and Silicate Concentration on Fly-Ash-Based Geopolymerization. Ind. Eng. Chem. Res. 2006, 45, 3559-3568. [CrossRef]

48. Hardjito, D.; Wallah, S.E.; Sumajouw, D.M.J.; Rangan, B.V. On the Development of Fly Ash-Based Geopolymer Concrete. ACI Mater. J. 2004, 101, 467-472.

49. Fang, S.; Lam, E.S.S.; Li, B.; Wu, B. Effect of Alkali Contents, Moduli and Curing Time on Engineering Properties of Alkali Activated Slag. Constr. Build. Mater. 2020, 249, 118799. [CrossRef]

50. Noushini, A.; Castel, A. The Effect of Heat-Curing on Transport Properties of Low-Calcium Fly Ash-Based Geopolymer Concrete. Constr. Build. Mater. 2016, 112, 464-477. [CrossRef]

51. Mangat, P.; Ojedokun, O. Influence of Curing on Pore Properties and Strength of Alkali Activated Mortars. Constr. Build. Mater. 2018, 188, 337-348. [CrossRef]

52. Sun, Z.; Vollpracht, A. Isothermal Calorimetry and In-Situ XRD Study of the Naoh Activated Fly Ash, Metakaolin and Slag. Cem. Concr. Res. 2018, 103, 110-122. [CrossRef]

53. Ma, Y.; Hu, J.; Ye, G. The Pore Structure and Permeability of Alkali Activated Fly Ash. Fuel 2013, 104, 771-780. [CrossRef]

54. Bernal, A.S.; DE Gutierrez, R.M.; Provis, J.; Rose, V. Effect of Silicate Modulus and Metakaolin Incorporation on the Carbonation of Alkali Silicate-Activated Slags. Cem. Concr. Res. 2010, 40, 898-907. [CrossRef]

55. Shi, J.; Ming, J. Influence of Defects at the Steel-Mortar Interface on the Corrosion Behavior of Steel. Constr. Build. Mater. 2017, 136, 118-125. [CrossRef]

56. Saetta, A.; Schrefler, B.A.; Vitaliani, R.V. The Carbonation of Concrete and the Mechanism of Moisture, Heat and Carbon Dioxide Flow through Porous Materials. Cem. Concr. Res. 1993, 23, 761-772. [CrossRef]

57. Shi, J.; Wu, M.; Ming, J. Long-Term Corrosion Resistance of Reinforcing Steel in Alkali-Activated Slag Mortar after Exposure to Marine Environments. Corros. Sci. 2021, 179, 109175. [CrossRef]

58. Leemann, A.; Moro, F. Carbonation of Concrete: The Role of $\mathrm{CO}_{2}$ Concentration, Relative Humidity and $\mathrm{CO}_{2}$ Buffer Capacity. Mater. Struct. 2017, 50, 1-14. [CrossRef]

59. Galan, I.; Andrade, C.; Castellote, M. Natural and Accelerated $\mathrm{CO}_{2}$ Binding Kinetics in Cement Paste at Different Relative Humidities. Cem. Concr. Res. 2013, 49, 21-28. [CrossRef]

60. Nedeljković, M.; Ghiassi, B.; van der Laan, S.; Li, Z.; Ye, G. Effect of Curing Conditions on the Pore Solution and Carbonation Resistance of Alkali-Activated Fly Ash and Slag Pastes. Cem. Concr. Res. 2019, 116, 146-158. [CrossRef]

61. Xu, H.; Provis, J.L.; van Deventer, J.S.J.; Krivenko, P.V. Characterization of Aged Slag Concretes. ACI Mater. J. 2008, 105, 131-139. [CrossRef]

62. Pasupathy, K.; Berndt, M.; Castel, A.; Sanjayan, J.; Pathmanathan, R. Carbonation of a Blended Slag-Fly Ash Geopolymer Concrete in Field Conditions After 8 Years. Constr. Build. Mater. 2016, 125, 661-669. [CrossRef]

63. Bernal, A.S.; Nicolas, R.S.; Myers, R.; De Gutierrez, R.M.; Puertas, F.; van Deventer, J.S.; Provis, J. MgO content of Slag Controls Phase Evolution and Structural Changes Induced by Accelerated Carbonation in Alkali-Activated Binders. Cem. Concr. Res. 2014, 57, 33-43. [CrossRef]

64. Mo, L.; Panesar, D.K. Accelerated Carbonation-A Potential Approach to Sequester $\mathrm{CO}_{2}$ in Cement Paste Containing Slag and Reactive MgO. Cem. Concr. Compos. 2013, 43, 69-77. [CrossRef] 
65. Shi, Z.; Shi, C.; Wan, S.; Li, N.; Zhang, Z. Effect of Alkali Dosage and Silicate Modulus on Carbonation of Alkali-Activated Slag Mortars. Cem. Concr. Res. 2018, 113, 55-64. [CrossRef]

66. Ismail, I.; Bernal, A.S.; Provis, J.; Nicolas, R.S.; Brice, D.G.; Kilcullen, A.R.; Hamdan, S.; van Deventer, J.S. Influence of Fly Ash on the Water and Chloride Permeability of Alkali-Activated Slag Mortars and Concretes. Constr. Build. Mater. 2013, 48, 1187-1201. [CrossRef]

67. Babaee, M.; Castel, A. Chloride Diffusivity, Chloride Threshold, and Corrosion Initiation in Reinforced Alkali-Activated Mortars: Role of Calcium, Alkali, And Silicate Content. Cem. Concr. Res. 2018, 111, 56-71. [CrossRef]

68. Wang, S.-D.; Scrivener, K.L. Hydration Products of Alkali Activated Slag Cement. Cem. Concr. Res. 1995, 25, 561-571. [CrossRef]

69. Ben Haha, M.; Lothenbach, B.; LE Saout, G.; Winnefeld, F. Influence of Slag Chemistry on the Hydration of Alkali-Activated Blast-Furnace Slag-Part I: Effect of MgO. Cem. Concr. Res. 2011, 41, 955-963. [CrossRef]

70. Ye, H.; Huang, L.; Chen, Z. Influence of Activator Composition on The Chloride Binding Capacity of Alkali-Activated Slag. Cem. Concr. Compos. 2019, 104. [CrossRef]

71. Ben Haha, M.; Lothenbach, B.; LE Saout, G.; Winnefeld, F. Influence of Slag Chemistry on the Hydration of Alkali-Activated Blast-Furnace Slag-Part II: Effect of $\mathrm{Al}_{2} \mathrm{O}_{3}$. Cem. Concr. Res. 2012, 42, 74-83. [CrossRef]

72. Kupwade-Patil, K.; Allouche, E.N. Examination of Chloride-Induced Corrosion in Reinforced Geopolymer Concretes. J. Mater. Civ. Eng. 2013, 25, 1465-1476. [CrossRef]

73. Monticelli, C.; Natali, M.; Balbo, A.; Chiavari, C.; Zanotto, F.; Manzi, S.; Bignozzi, M. Corrosion Behavior of Steel in AlkaliActivated Fly Ash Mortars in the Light of their Microstructural, Mechanical and Chemical Characterization. Cem. Concr. Res. 2016, 80, 60-68. [CrossRef]

74. Monticelli, C.; Natali, M.; Balbo, A.; Chiavari, C.; Zanotto, F.; Manzi, S.; Bignozzi, M. A Study on the Corrosion of Reinforcing Bars in Alkali-Activated Fly Ash Mortars under Wet and Dry Exposures to Chloride Solutions. Cem. Concr. Res. 2016, 87, 53-63. [CrossRef]

75. Noushini, A.; Castel, A.; Aldred, J.; Rawal, A. Chloride Diffusion Resistance and Chloride Binding Capacity of Fly Ash-Based Geopolymer Concrete. Cem. Concr. Compos. 2020, 105, 103290. [CrossRef]

76. Palomo, A.; Grutzeck, M.; Blanco-Varela, M.T. Alkali-Activated Fly Ashes: A Cement for the Future. Cem. Concr. Res. 1999, 29, 1323-1329. [CrossRef]

77. Chindaprasirt, P.; Chalee, W. Effect of Sodium Hydroxide Concentration on Chloride Penetration and Steel Corrosion of Fly Ash-Based Geopolymer Concrete under Marine Site. Constr. Build. Mater. 2014, 63, 303-310. [CrossRef]

78. Chang, H. Chloride Binding Capacity of Pastes Influenced by Carbonation under Three Conditions. Cem. Concr. Compos. 2017, 84, 1-9. [CrossRef]

79. Ke, X.; Bernal, S.A.; Provis, J.L. Uptake of Chloride and Carbonate by Mg-Al and Ca-Al Layered Double Hydroxides In Simulated Pore Solutions of Alkali-Activated Slag Cement. Cem. Concr. Res. 2017, 100, 1-13. [CrossRef]

80. Zheng, Y.; Russell, M.; Davis, G.; McPolin, D.; Yang, K.; Basheer, P.; Nanukuttan, S. Influence of Carbonation on the Bound Chloride Concentration in Different Cementitious Systems. Constr. Build. Mater. 2021, 302, 124171. [CrossRef]

81. Sun, M.; Sun, C.; Zhang, P.; Liu, N.; Li, Y.; Duan, J.; Hou, B. Influence of Carbonation on Chloride Binding of Mortars Made with Simulated Marine Sand. Constr. Build. Mater. 2021, 303, 124455. [CrossRef]

82. Shi, J.; Ming, J.; Sun, W. Electrochemical Behaviour of a Novel Alloy Steel in Alkali-Activated Slag Mortars. Cem. Concr. Compos. 2018, 92, 110-124. [CrossRef]

83. Shi, J.; Ming, J.; Sun, W. Electrochemical Performance of Reinforcing Steel in Alkali-Activated Slag Extract in the Presence of Chlorides. Corros. Sci. 2018, 133, 288-299. [CrossRef]

84. Shi, J.; Ming, J.; Wu, M. Passivation and Corrosion Behavior of 2304 Duplex Stainless Steel in Alkali-Activated Slag Materials. Cem. Concr. Compos. 2020, 108, 103532. [CrossRef]

85. Angst, U.M.; Geiker, M.R.; Alonso, M.C.; Polder, R.; Isgor, O.B.; Elsener, B.; Wong, H.; Michel, A.; Hornbostel, K.; Gehlen, C.; et al. The Effect of the Steel-Concrete Interface on Chloride-Induced Corrosion Initiation in Concrete: A Critical Review by RILEM TC 262-SCI. Mater. Struct. 2019, 52, 1-25. [CrossRef]

86. Chen, R.; Hu, J.; Ma, Y.; Guo, W.; Huang, H.; Wei, J.; Yin, S.; Yu, Q. Characterization of the Passive Film Formed on the Reinforcement Surface in Alkali Activated Fly Ash: Surface Analysis and Electrochemical Evaluation. Corros. Sci. 2020, 165, 108393. [CrossRef]

87. You, N.; Shi, J.; Zhang, Y. Corrosion Behaviour of Low-Carbon Steel Reinforcement in Alkali-Activated Slag-Steel Slag and Portland Cement-Based Mortars under Simulated Marine Environment. Corros. Sci. 2020, 175, 108874. [CrossRef]

88. Scott, A.; Alexander, M. Effect of Supplementary Cementitious Materials (Binder Type) on the Pore Solution Chemistry and the Corrosion of Steel in Alkaline Environments. Cem. Concr. Res. 2016, 89, 45-55. [CrossRef]

89. Mangat, P.; Ojedokun, O.O.; Lambert, P. Chloride-Initiated Corrosion in Alkali Activated Reinforced Concrete. Cem. Concr. Compos. 2021, 115, 103823. [CrossRef]

90. Elsener, B.; Andrade, C.; Gulikers, J.; Polder, R.; Raupach, M. Half-Cell Potential Measurements—Potential Mapping on Reinforced Concrete Structures. Mater. Struct. 2003, 36, 461-471. [CrossRef]

91. Lv, W.; Sun, Z.; Su, Z. Study of Seawater Mixed One-Part Alkali Activated GGBFS-Fly Ash. Cem. Concr. Compos. 2020, 106. [CrossRef]

92. Elsener, B. Half-Cell Potential Mapping to Assess Repair Work on RC structures. Constr. Build. Mater. 2001, 15, 133-139. [CrossRef] 
93. Criado, M.; Bernal, S.A.; Trinanes, P.G.; Provis, J.L. Influence of Slag Composition on the Stability of Steel in Alkali-Activated Cementitious Materials. J. Mater. Sci. 2018, 53, 5016-5035. [CrossRef]

94. Gunasekara, C.; Law, D.; Bhuiyan, S.; Setunge, S.; Ward, L. Chloride Induced Corrosion in Different Fly Ash Based Geopolymer Concretes. Constr. Build. Mater. 2018, 200, 502-513. [CrossRef]

95. Batis, G.; Pantazopoulou, P.; Tsivilis, S.; Badogiannis, E. The Effect of Metakaolin on the Corrosion Behavior of Cement Mortars. Cem. Concr. Compos. 2005, 27, 125-130. [CrossRef]

96. Hossain, M.; Karim, M.; Elahi, M.; Islam, M.; Zain, M. Long-Term Durability Properties of Alkali-Activated Binders Containing Slag, Fly Ash, Palm Oil Fuel Ash and Rice Husk Ash. Constr. Build. Mater. 2020, 251, 119094. [CrossRef]

97. Buchanan, R.A.; Stansbury, E.E. Electrochemical Corrosion. In Handbook of Environmental Degradation of Materials, 2nd ed.; Elsevier: Amsterdam, The Netherlands, 2012; pp. 87-125.

98. Andrade, F.D.C.; González, J.A. Quantitative Measurements of Corrosion Rate of Reinforcing Steels Embedded in Concrete Using Polarization Resistance Measurements. Mater. Corros. 1978, 29, 515-519. [CrossRef]

99. Elsener, B. Corrosion Rate of Steel in Concrete-Measurements Beyond the Tafel Law. Corros. Sci. 2005, 47, 3019-3033. [CrossRef]

100. Ge, J.; Isgor, O. Effects of Tafel Slope, Exchange Current Density and Electrode Potential on the Corrosion of Steel in Concrete. Mater. Corros. 2007, 58, 573-582. [CrossRef]

101. Chang, Z.-T.; Cherry, B.; Marosszeky, M. Polarisation Behaviour of Steel Bar Samples in Concrete in Seawater. Part 1: Experimental Measurement of Polarisation Curves of Steel in Concrete. Corros. Sci. 2008, 50, 357-364. [CrossRef]

102. Pour-Ghaz, M.; Isgor, B.; Ghods, P. The Effect of Temperature on the Corrosion of Steel in Concrete. Part 1: Simulated Polarization Resistance Tests and Model Development. Corros. Sci. 2009, 51, 415-425. [CrossRef]

103. Valencia-Saavedra, W.G.; Aguirre-Guerrero, A.M.; De Gutiérrez, R.M. Alkali-Activated Concretes Based on High Unburned Carbon Content Fly Ash: Carbonation and Corrosion Performance. Eur. J. Environ. Civ. Eng. 2020, 1-21. [CrossRef]

104. Aguirre-Guerrero, A.M.; Robayo-Salazar, R.A.; de Gutiérrez, R.M. Corrosion Resistance of Alkali-Activated Binary Reinforced Concrete Based on Natural Volcanic Pozzolan Exposed to Chlorides. J. Build. Eng. 2021, 33, 101593. [CrossRef] 